\title{
THE PROCEDURAL PROTECTION OF DATA DE-INDEXING IN INTERNET SEARCH ENGINES: THE EFFECTIVENESS IN BRAZIL OF THE SO-CALLED “RIGHT TO BE FORGOTTEN” AGAINST MEDIA COMPANIES
}

\section{A TUTELA PROCESSUAL DA DESINDEXAÇÃO DE DADOS EM FERRAMENTAS CIBERNÉTICAS DE BUSCA: A EFETIVAÇÃO NO BRASIL DO CHAMADO “DIREITO AO ESQUECIMENTO” EM FACE DAS EMPRESAS DE COMUNICAÇÃO}

GILBERTO FACHETTI SILVESTRE Doctor in Civil Law by the Pontifícia Universidade Católica de São Paulo (PUC/SP). Professor of the Graduation in Law and the Master in Procedural Law of the Universidade Federal do Espírito Santo (UFES). Lawyer.

CAROLINA BIAZATTI BORGES Master in Procedural Law by the Universidade Federal do Espírito Santo (UFES). CAPES scholarship holder. Lawyer.

NAUANI SCHADES BENEVIDES Master in Procedural Law by the Universidade Federal do Espírito Santo (UFES). FAPES scholarship holder. Lawyer. 


\section{ABSTRACT}

The right to be forgotten is recognized by the brazilian courts as embodied in the protection of human dignity. However, in the contemporary virtual environment, this right faces severe difficulties to be made effective, demanding instruments compatible with i) the dynamics of virtual relations; ii) the importance of conflicting - personal and public legal assets; iii) the functioning mechanisms of virtual structures; and iv) the technical capacity for cessation or mitigation of the damage of the individuals involved. In this context, this research analyzes the viability of procedural protection of the right to be forgotten in Brazil through the de-indexing of data, recognizing the active role of search engine companies in its effectiveness before media companies. Methodologically, the study is based on a documentary research, done on a sampling of the brazilian legal literature and of the paradigmatic judgments of the brazilian Superior Court of Justice (SCJ). Also, a qualitative research was carried out, as it analyzed the foundations and effects verified in the samplings of those documents. There was also a quali-quantitative research of the decisions of the Superior Court of Justice aiming to verify if there is jurisprudence, or only isolated decisions. The deductive method was used, with the major premise - taken to be true - that it is possibile to extend the application's spectrum of the protection of the right to be forgotten, and secondly, that the SCJ has a conservative position regarding the role of search engines.

KEYWORDS: Civil Procedural Law; Data de-indexing; Right to be forgotten; Search engines.

\section{RESUMO}

O direito ao esquecimento é reconhecido pelo Judiciário como inserido na tutela da dignidade da pessoa humana. Entretanto, no ambiente virtual contemporâneo, esse direito enfrenta severas dificuldades para ser efetivado, demandando instrumentos compatíveis com a dinamicidade das relações virtuais, a importância dos bens jurídicos 
— pessoais e públicos - em conflito, os mecanismos de funcionamento das estruturas virtuais e a capacidade técnica dos sujeitos envolvidos para cessação ou mitigação do dano. Nesse contexto, esta pesquisa analisa a viabilidade de tutela processual do direito ao esquecimento no Brasil por meio da desindexação de dados, reconhecendo-se o papel ativo das empresas motores de busca na sua efetivação perante as empresas de comunicação. Metodologicamente, o trabalho se fundamenta em uma pesquisa documental, feita sobre uma amostragem da literatura jurídica brasileira e de julgados paradigmáticos do Superior Tribunal de Justiça (STJ). Outrossim, procedeu-se a uma pesquisa qualitativa, pois analisou os fundamentos e efeitos verificados nas amostragens daqueles documentos. Houve, ainda, uma pesquisa qualiquantitativa, dos julgados do Superior Tribunal de Justiça objetivando verificar se há jurisprudência, ou apenas julgados isolados. Empregou-se o método dedutivo, tendo por premissa maior, considerada verdadeira, a possibilidade de ampliar o espectro de aplicação da proteção do direito ao esquecimento, e por segunda premissa, que o STJ apresenta posição conservadora em relação ao papel dos motores de busca.

PALAVRAS-CHAVE: Processo civil; Desindexação de informações; Direito ao esquecimento; Motores de busca.

\section{INTRODUCTION}

The "right to be forgotten", despite the inadequacy of terminology, refers to the right of the individual that there is no current placement - either by editing a new document or by making old news available - of certain past facts related to his or her life, even if there has been a licit circulation of these facts in the past. In this way, this right aims to avoid that the truthful fact of the past causes present disturbance to the individual who carried it out or simply experienced it. 
Although "right to be forgotten" is an expression consecrated by the use in several languages (French: droit d'oubli, Spanish: derecho al olvido, German: Recht auf Vergessenwerden, Portuguese: Direito ao esquecimento), its inadequacy is verified in the fact that in order to be entitled to be forgotten it would be necessary to impose on others the mental duty to forget, which does not seem to be legally possible. In fact, forgetting, in a legal sense, is the consequence of the difficulty in remembering something whose physical records have been erased (TEFFÉ and BARLETTA, 2016).

In Brazil, there is no express legislative provision for the right to be forgotten, but it has already been the subject of numerous lawsuits and on several occasions the brazilian courts have declared its recognition in the legal system. Among the highlighted decisions in the scope of the brazilian Superior Court of Justice (SCJ) are the Recurso Especial (Resp) nr. 1.335.153/RJ (Case Aída Curi), the REsp nr. 1.334.097/RJ (Case Chacina da Candelária), the REsp nr. 1.316.921/RJ (Case Xuxa Meneghel) and the HC 256.210/SP (Case of Mario de Assis Gomes). From these decisions, it is infered the necessity to balance the right to be forgotten with the press freedom and, consequently, the right to information, so it is imperative to analyze the degree of public interest in the information that is intended to "impose forgetfulness".

In addition to the constant conflict between the right to be forgotten and communicative freedoms, there is another complicating factor: the variety of means of communication through which it is possible to transgress it. In traditional media, such as printed newspapers and magazines, television and radio, the protection of the right to be forgotten is simpler, since it is easy to identify the issuer of the information, as well as its withdrawal from circulation, which is usually transmitted in short term and has controllable replicability. However, in the digital environment, this situation is much more complex, because on the web information tends to be available by a single click, its replicability by another pages is incalculable and it is difficult to identify its publisher.

At this matter, the brazilian courts, in its majority, have decided that the victim needs to file a lawsuit directly to the editor of the law-breaking virtual page, and there is no recognition that search engines - such as Google, Yahoo! and Bing - have any role 
in contributing to the enforcement of the right to be forgotten. This understanding, established in the judgment of the case Xuxa Meneghel v. Google Search (REsp nr. 1.316.921/RJ), is based on a supposed neutrality of search engines in relation to the information made available on the web by third parties. And such decision, as a normative binding precedent (ZANETI JR, 2017) - although not formally binding under the terms of article 927 of the Code of Civil Procedure of 2015 (CCP/15) - , has served as a decisionmaking standard for the decisions that came later such as the Ag. Int.'s decision in the REsp. nr. 1.593.873/SP and numerous decisions in the state courts of the southeastern region of Brazil, such as Ap. nr. 2186767-30.2014.8.26.0000 from the State Court of Justice of São Paulo (SCJSP), Ag. Inst. nr. 2186767-30.2014.8.26.0000 from SCJSP, Ap. nr. 1126822-86.2015.8.26.0100 from SCJSP, Ap. nr. 0132165-85.2012.8.26.0100 from SCJSP and Ap. nr. 0002133-98.2016 .8.19.0050 from State Court of Justice of Rio de Janeiro (SCJRJ), in which either: a) the right to be de-indexed was denied in dismissal with prejudice (decision on merit) or b) the lawsuit was dismissed b.1) by the lack of standing to be sued (illegitimacy as defendant) of the search engine companies or b.2) by the lack of justiciable controversy (procedural interest) in the case.

Therefore there is a problem to be solved. This conservative position of the courts leads to frustration of the right to be forgotten in the virtual scope, so it is necessary the re-evaluate the role of search engines in order to guarantee to the victims that they refrain from showing certain virtual pages in their results. Thus, the research analyzed the legal feasibility of filing a legal claim to protect the right to be forgotten against search engines by requesting de-indexation of virtual pages. To achieve this, the legal nature of the right to be forgotten, the parties against which it may be demanded and national and international judicial decisions (standards) about de-indexation were analyzed in order to identify the type of action that may be appropriate, the specific requests on the methodology of de-indexation, the characterization of the procedural interest, the legitimacy, the applicability of a fine for noncompliance and the possibility of provisional protection of urgency. 
The methodology of this research consisted in the bibliographical revision of brazilian and foreign legal literature, as well as the documental analysis of judicial decisions. All to confirm the applicability of the central hypothesis of the research and demonstrate the need to attribute responsibility to the search engine companies for the solution of procedural litigation with equity.

The paper is based on a documentary research, done on a sampling of the brazilian juridical literature and of paradigmatic judgments of the brazilian Superior Court of Justice (SCJ). Also, a qualitative research was carried out, as it analyzed the foundations and effects verified in the samplings of those documents. There was also a quali-quantitative research of the decisions of the Superior Court of Justice aiming to verify if there is jurisprudence, or only isolated decisions.

The deductive method was used, with the major premise - taken to be true that it is possibile to extend the application's spectrum of the protection of the right to be forgotten, and secondly, that the SCJ has a conservative position regarding the role of search engines.

The contribution that this research intends to give to the development of the legal knowledge is to offer arguments, based on systematic interpretation, for the necessary protection of the right of being de-indexed.

\section{THE "RIGHT TO BE FORGOTTEN" AS A PERSONALITY RIGHT}

The right to be forgotten originates in the study of the privacy protection, but in Brazil it was in the criminal sphere that it developed the most (RULLI JÚNIOR and RULLI NETO, 2012). This statement gets clear in the analysis of the right of detachment of the convicted person to the memory of the crime after the sentence has been served in order to ensure the resocialization. There are several institutes and legal provisions of criminal legislation in this sense, highlighting the article 93 of the Criminal Code (Decree-Law nr. 2.848/1940), the article 748 of the Code of Criminal Procedure (Decree-Law nr. 
3.689/1941) and the article 202 of the Criminal Enforcement Law (Law nr. 7.210/1984), which expressly prohibit the maintenance of past conviction`s records of the offender who has fully served the sentence, except to instruct the procedure to pursuit a new criminal offense. See, in verbis, the free translation of the mentioned devices:

Art. 93. Rehabilitation reaches any penalties in final judgment, ensuring the convict confidentiality of records about his prosecution and conviction. [...] Art. 748. The previous sentence or sentences will not be mentioned in the history of rehabilitated wrapper or extracted certificate of judgment books, except when required by the criminal judge. [...] Art. 202. Once the sentence has been fulfilled or extinguished, there will be no news or references to the conviction in the history of rehabilitated wrapper or in certificates issued by the police authority or by legal assistants, except for investigating the prosecutin for the commission of new criminal offenses or other cases expressed by law.

In the brazilian legal system, the right to be forgotten acts in the protection of the personal identity of the individual, preventing certain facts and information - that attain or not the honor of the individual —, from being stored definitely in the collective memory. Thus, it is based on the principle of human dignity, inscribed in subsection III of article $1^{\text {st }}$ of the brazilian Federal Constitution of 1988.

Given the importance of this right and its merely implicit prevision on brazilian statutes, in 2003 it was approved in the VI Conference of Civil Law of the Federal Justice Council the Statement nr. 531 relating to the art. 11 of the Civil Code, which explicitly recognizes the right to be forgotten as included in the protection of the human dignity in the information society: "Statement 531 - The protection of the human dignity in the information society includes the right to be forgotten" (free translated).

Moreover, given its recognition as a personality right, the right to be forgotten is assured by the $5^{\text {th }}$ article of the brazilian Federal Constitution of 1988 , in which privacy, private life, honor and the image of individuals are guaranteed, as well as in Chapter II of the brazilian Civil Code, which refers to the protection of the personality rights (articles 11 to 21).

Likewise, personality rights and fundamental rights refer to every power that is given to a person to protect protect and preserve his or her dignity. Therefore, these rights 
are foreseen in numerus apertus in the legal system, precisely to ensure the adequacy of the protection to new rights that arise with the passage of time and social changes.

Thus, based on an analysis of these legal provisions and judicial decisions on the subject, it is possible to conceptualize the right to be forgotten as an autonomous personality right (VICENTE, 2004), which guarantees to the individual the right to demand the exclusion of information about him or her when sufficient time has elapsed to render it useless. It is a right that is in constant conflict with other rights such as the right to access information and freedoms such as expression, scientific, artistic, literary and journalistic freedoms, which is why it is indispensable to always proceed with a balance between them (BENEVIDES and SILVESTRE, 2016).

Due to its personality right quality, the right to be forgotten is classified as inalienable, unwaivable, untransferable, unattachable and absolute. This last aspect, the absolute feature, must be understood as opposable erga omnes and not as unlimited, since the right to be forgotten is in constant conflict with other rights and therefore it is necessary to consider when a right overlaps temporarily on the other in specific concrete cases.

\subsection{THE RIGHT TO BE FORGOTTEN AND THE MEDIA COMPANIES}

The considerable number of judgments about the right to be forgotten leads to the conclusion that it is incontestably recognized by the brazilian courts when the lawsuit is filed against the party who effectively transmitted the information, whether the party is a traditional communication vehicle (radio, printed periodicals, television etc.) or virtual environment (news websites, blogs, vlogs, social networks etc.). Thus, despite the cases in which the right to be forgotten is denied by weighing conflicting rights, the Judiciary has acknowledged the existence of the procedural presuppositions for the filing a judicial claim to pursue its protection, hence the lawsuit is shown as a useful, necessary and adequate means for the accomplishment of the right to be forgotten, and it is rightful the requirement 
that the individual who transmitted the violating information be held responsible for their harmful conduct.

Regarding lawsuits against traditional media companies, Fernanda Freire dos Santos (2017) points out as paradigmatic the following cases:

\begin{tabular}{|c|c|}
\hline CASE & REFERENCE \\
\hline "Aída Curi" & $\begin{array}{l}\text { SCJ, REsp nr. } 1.335 .153,4^{\text {th }} \text { Panel, Reporting Justice Luis Felipe } \\
\text { Salomão, trial in: May } 28^{\text {th }}, 2013 \text {, DJe: May } 28^{\text {th }}, 2013 .\end{array}$ \\
\hline "Doca Street" & $\begin{array}{l}\text { SCJRJ, Civil Appeal nr. } 2005.001 .54774,5^{\text {th }} \text { Civil Chamber, Reporting } \\
\text { Justice Milton Fernandes de Souza, trial in: March } 28^{\text {th }}, 2006 \text {, DJRJ: } \\
\text { May } 12^{\text {th }}, 2006 .\end{array}$ \\
\hline $\begin{array}{l}\text { "Chacina da } \\
\text { Candelária" }\end{array}$ & $\begin{array}{l}\text { SCJ, REsp nr. } 1.334 .097,4^{\text {th }} \text { Panel, Reporting Justice Luis Felipe } \\
\text { Salomão, trial in: May } 28^{\text {th }}, 2013 \text {, DJe: September } 10^{\text {th }}, 2013 \text {. }\end{array}$ \\
\hline
\end{tabular}

All these cases concerned the protection of the right to be forgotten against Rede Globo de Televisão Ltda (a brazilian mass media company), for broadcasting or threatening to broadcast in the television program "Linha Direta" the reconstitution of crimes that occurred in the past, bringing to the present moment of that time a dishonorable memory to the plaintiffs, who were, in the first case, the family of the deceased victim Aida Curi and in the last two cases, the acquitted defendants of previous murder charges.

In the "Aída Curi" case, the State Court of Justice of of Rio de Janeiro (SCJRJ), although acknowledging the existence of a right to be forgotten, dismissed the claims of the victim's relatives on the grounds that it was a historical crime and that it would be fundamental to the retraction of the case that both name and image of the victim were used. In addition, the court underlined that the long period of fifty years since the crime occurred entailed in the reduction of the pain and the emotion of the memory.

In the "Doca Street" case, the former accused's claim, despite being granted at first instance, was rejected by the SCJRJ on the grounds that the freedom of expression of the television broadcaster should prevail over the right to be forgotten on that specific occasion. That is because, according to the court, the defendant (media company) merely reported the facts on the basis of the documented evidence at the time of the crime. In 
addition, the court mentioned the need of prevalence of the population right to remember the identity of criminals.

Finally, in the "Chacina da Candelária" case, the SCJ upheld the decision of the SCJRJ to grant the former accused's claim, condemning the television broadcaster to indemnify him on the grounds of the disclosure of his image and name when it was not justified. According to the court, it was proved that the alleged participation of the exaccused (deemed innocent) would be merely secondary and ancillary, so that there would be no public interest in reporting it and there would be no loss of information if a pseudonym was used.

Although the outcome of only one of the three cases cited has privileged the right to be forgotten to the detriment of other rights and although there are very subjective criteria in deciding each case, the viability of protecting the right to be forgotten in the television media through a negative covenant action in cases of threat of the information disclosure or indemnification action in cases where the information has already been transmitted and the damage perpetrated is clear. As for other traditional means of communication, there are no substantial differences in relation to the television media, imposing identical treatment on its protection. Such simplicity, however, does not occur in digital media.

In the digital environment, unlike the physical environment of traditional media, information is rarely lost, erased and therefore forgotten (TRIGUEIRO, 2016). A simple web search through search engines such as Google allows the access to a varied list of information and news from present and past facts, endowed (or not) with of public interest, as well as a number of private information that without the party's consent were made available in this public environment.

Thus, since the "internet never forgets" (KEEN, 2012), the violation of the right to be forgotten is not limited to the edition of news or new features that relives information and facts of the past, as occurs in traditional media. In the digital sphere, the information in its original publication made at that time in a licit way may become illegal and violator 
of rights over time. And it is the web search sites, so-called search engines, that with a simple click are able to bring up information and long-forgotten facts.

In this context, considering that access to pages that violate the right to be forgotten is almost exclusively franchised by search engine companies, in particular by Google Search - which is the search engine used by $94,27 \%$ of web users in Brazil (STATCOUNTER GLOBAL STATS, 2018) - , it has been increasingly common to file lawsuits against these searchers to protect the right to be forgotten by deindexing rightsinfringing content, even though the search engine is not the party that edited, hosted and originally served the content.

\subsection{THE RIGHT TO BE FORGOTTEN AND SEARCH ENGINE COMPANIES: THE RIGHT TO DE-INDEXING INFORMATION}

The leading case in the recognition of the right to de-indexation is González vs. Google Spain, judged by the Court of Justice of the European Union in 2014 (Case Nr. C131/12). In that case, Mario Costeja González claimed Google to be forced to withdraw from the search results the links that led to two newspaper announcements, dated from 1998, regarding the execution of a debt with Social Security contained in the virtual repository of the newspaper La Vanguardia.

At that time, by the reason that the presence of such information was legally justified in the newspaper, since it was part of the digital newspaper library and contained historical value, the court denied the claim made directly against La Vanguardia for deletion or alteration of the specific pages. However, the claim for exclusion of the links that led to the news, based on the right to de-indexation, was granted, thus overcoming the idea of neutrality of search engines and recognizing that Google's activity subsumes the concept of data processing (COURT OF JUSTICE OF THE EUROPEAN UNION, 2014, paragraph nr. 33).

During the trial of this case, there was a detailed study on how Google and other search engine companies work. It was concluded that the activity of searching for content 
published on the internet by third parties, automatically indexing this content, temporarily storing it and arranging them to the searcher in an order of preference determined by algorithms is classified as a personal data processing activity. So, the one who treats such data is liable for the protection of the right to be forgotten. See:

Article 2(b) and (d) of Directive 95/46/EC of the European Parliament and of the Council of 24 October 1995 on the protection of individuals with regard to the processing of personal data and on the free movement of such data are to be interpreted as meaning that, first, the activity of a search engine consisting in finding information published or placed on the internet by third parties, indexing it automatically, storing it temporarily and, finally, making it available to internet users according to a particular order of preference must be classified as 'processing of personal data' within the meaning of Article 2(b) when that information contains personal data and, second, the operator of the search engine must be regarded as the 'controller' in respect of that processing, within the meaning of Article 2(d). (COURT OF JUSTICE OF THE EUROPEAN UNION, 2014, section 1 of the Operative part of the judgment).

After the judgment of the paradigmatic case González vs. Google Spain, the legal systems of the European Union countries have come to recognize the right of individuals, who have content about themselves on the internet that violates their right to be forgotten, to plead before the search engines companies the withdrawal of links that lead to the infringing pages of any websites. This pleading does not depend on the withdrawal of the content by the website that acctually originated the violation. The adoption of this posture led search engines companies to provide forms to internet users for requesting deindexation, so such activity could be done extrajudicially.

Whereas the European Union decides on the feasibility of protecting the right to de-indexation against search engine companies, in the United States - although it is agreed that search engines effectively do data processing and that they are not neutral internet players - it is argued the impossibility of filing lawsuits based on the right to deindexation. For american courts, search engine activity falls within the concept of speaker and would therefore be protected by the freedom of expression guaranteed in the First Amendment of United States Constitution (VOLOKH e FALK, 2012). 
The United States and the European Union, while reaching divergent conclusions regarding the protection of the right to de-indexation, share a convergent understanding in their rationale: they recognize that search engines, by means of complex algorithms, treat personal data in the performance of their profitable activity; ergo, both assign an active role to such search engines in the virtual environment.

On the other hand, brazilian courts use as main argument to prevent the protection of the right to be forgotten, through de-indexation, the recognition of neutrality of the search engines in relation to the content arranged in the search results.

The brazilian leading case on this subject is the case Xuxa Meneghel vs. Google Search, which refers to a lawsuit filed by an actress and presenter nationally known for presenting children's television shows against the Google search engine, requesting the removal of links from websites that appeared in the search result for the words "Xuxa Pedófila" (REsp nr. 1.316.921/RJ).

The presenter acquired a bad reputation after the viral propagation of a film made in the beginning of her career, in which she starred naked with a minor. Regarding the plaintiff's claim, the Superior Court of Justice: i) emphasized the technical difficulty in complying with the pleading; ii) underlined the need to preserve the right to information; iii) acknowledged Google's illegitimacy in regards to the removal of offensive content from the Internet that was viewable in the outcome of its searches, given the neutral and impartial role of search engines, which do not create, store and organize content, nor exercise control over search results. See the summary of the judgment freely translated:

CIVIL AND CONSUMER. INTERNET. CONSUMER RELATION. INCIDENCE OF CCD. FREE SERVICE. INDIFFERENCE. RESEARCH PROVIDER. FILTRAGE. PREVIOUS SEARCHES. UNNECESSITY. RESTRICTION OF RESULTS. NONAPPLICABILITY. PUBLIC CONTENT. RIGHT TO INFORMATION. 1. The commercial exploitation of the Internet leads the consumer relations arising from that environment to be ruled by Law nr. 8.078/90 (CCD). 2. The fact that the service provided by the Internet service provider is free does not distort the consumption relation, since the term "for remuneration", contained in article $3^{\text {rd }}$, $\S 2^{\text {nd }}$ of the CDC, should be interpreted broadly to include the supplier's indirect gain. 3 . The search engine is a specie of the content provider genus, as it does not include host, organize or otherwise manage the virtual pages indicated in the results available, but only indicates links where the terms or expressions searched by the user can be found. 4 . The filtering of the search's content done by each user does not 
constitute an intrinsic activity of the service provided by the search engines, so the website that does not exercise this control over the search results can not be considered defective, under the terms of article 14 of CCD. 5. Research providers conduct their searches within a virtual universe, whose access is public and unrestricted, that is, their role is restricted to the identification of webpages where certain data or information, although illicit, are being freely transmitted. Thus, although their search mechanisms facilitate access and the consequent disclosure of pages whose content is potentially illegal, the fact is that these pages are public and compose the global computer network and therefore appear in the result of the search engines. 6 . Search engines may not be forced to eliminate from their system the results derived from the search for a certain term or expression, nor the results that point to a specific photo or text, regardless of whether the user indicates the $U R L$ of the page where this is inserted. 7 . It is not possible, under the pretext of prevent from the illegal or offensive propagation of content on the web, to suppress the right of the collectivity to information. Having weighed the rights involved and the potential risk of violation of each one of them, the balance should be tipped in favor of the guarantee of the freedom of information provided by the article 220 , $\S$ $1^{\circ}$, of the FC/1988, especially considering that the Internet represents, today, an important mass media vehicle. 8. Once the requirements for the deletion of a particular webpage have been fulfilled, on the grounds that it is intended to convey illegal or offensive content - notably the identification of the URL of that page - the victim will have no interest in acting against the search provider, absolute lack of utility of the jurisdiction. If the victim has identified, by URL, the author of the wrongful act, there is no reason to sue the one who only facilitates access to that act that until then is publicly available on the network for disclosure. 9. Recurso Especial granted. (SCJ, REsp nr. 1.316.921/RJ, $3^{\text {rd }}$ Panel, Reporting Justice Nancy Andrighi, trial in: June $26^{\text {th }}, 2012$, DJe: June $\left.29^{\text {th }}, 2012\right)$.

Therefore, according to the court, Google's activity is limited to helping users through its indexing service, not being responsible for the content of the information it displays. So, the offended individual should sue directly the editors of the offending page. In her opinion exposed in the judgment of the REsp. nr. 1.316.921/RJ, the Reporting Justice Nancy Andrighi, stated that search engines:

(i) do not respond to the content of the search results made by its users; (ii) can not be required to exercise prior control of the content of the search results made by each user; and (iii) can not be forced to eliminate from their system the results derived from the search for a certain term or expression, nor the results that point to a specific photo or text, regardless of the indication of the URL of the page where it is inserted. (Free translation).

Two years after the trial of the Xuxa Meneghel vs. Google Search case, the Law nr. 12.965/2014 (Civil Landmark of the Internet) was promulgated and brought in its article $7^{\text {th }}$, items I and X, normative tools to the protection of the right to be forgotten: 
Art. $7^{\text {th }}$. Internet access is essential to the exercise of citizenship, and it is assured to the user the following rights: I - inviolability of privacy and personal life, its protection and compensation for material or moral damage resulting from its violation; [...] X - definitive exclusion of the user's personal data provided to a certain Internet application, through the user's request, at the end of the relation between the parties, except for the hypotheses of mandatory record keeping provided in this Law. (Free translation).

However, the SCJ decided that the items I and X of article $7^{\text {th }}$ refer exclusively to cases where the user himself provides the content to the website and subsequently no longer wants it to store such information, not serving as a basis for any right to deindexation:

CIVIL AND CIVIL PROCEDURE. RECURSO ESPECIAL. AFFIRMATIVE COVENANT ACTION. SEARCH ENGINES. RIGHT TO BE FORGOTTEN. SEARCH PREVIOUS FILTERING. BLOCKING KEYWORDS. IMPOSSIBILITY. Right to be forgotten as "the right of one not to be remembered against one's will, specifically in regard to dissonant facts, of a criminal nature, in which he or she was involved, but which was subsequently acquitted." Precedents. - Search engines may not be forced to eliminate from their system the results derived from the search for a certain term or expression, nor the results that point to a specific photo or text, regardless of the indication of the page where it is inserted. - Absence of a normative ground to impute to Internet search engines the obligation to implement the right to be forgotten and, thus, to exercise the function of digital censor. Recurso Especial granted. (SCJ. Ag. Inst. in REsp nr. 1.593.873, 3 $3^{\text {rd }}$ Panel, Reporting Justice Nancy Andrighi, trial in: November 10 ${ }^{\text {th }}, 2016$, DJe: November 17 1 th 2016 ). (Free translation).

Even though there are divergent decisions in the lower courts, the SCJ has stated that it is impossible to sue search engines pursuing the protection of the right to deindexation, replicating the grounds established in the Xuxa Meneghel vs. Google Search case (REsp nr. 1.316.921/RJ), justifying its decision basically in three arguments: 1) the technical impracticability of excluding certain results without prejudice to others or hackerproof exclusion; 2) the removal of information from the web always defies the right to information and memory; and 3) the neutrality of search engines.

Excluding the item ii, which should be measured casuistically by means of weighting rules, based, therefore, on items $\mathrm{i}$ and iii, the cases are extinguished on the grounds of lack of procedural interest and passive illegitimacy of search engine 
companies. This research revealed that this position is overly conservative and far from the factual reality about the subject.

\section{THE PROCEDURAL PROTECTION OF DATA DE-INDEXING: THE AFFIRMATIVE COVENANT ACTION AGAINST THE SEARCH ENGINE COMPANY}

As already explained, the right to be forgotten is a personality right guarateed by the article $5^{\text {th }}$ of the brazilian Federal Constitution and the effort to protect it is elementary. However, this right is in constant conflict with the rights of communicative liberties (TRIGUEIRO, 2016). It is in this context that the use of data de-indexing tool is fundamental for the simultaneous protection of both rights.

Websites that edit and store content enjoy freedom of expression and enable the right to information to the public. Although the lack of public interest and time lapse can assure to the individual to whom such content relates the right to plead for its erasure and consequent forgetfulness, it is true that a large part of the information is, albeit to a lesser extent, of some interest to some people or that such content is part of the historical collection of society, as in newspaper's digital library. Thus, it seems rare to be faced with a clear and simple case of supremacy of the right to be forgotten.

On the other hand, there is an evident harm to the individual who has his name raised in search results made by search engines, because sometimes the content is totally out of the original context and the search result leads to websites that the user who made the search could not even imagine existed (CURY NETO, 2015). Therefore, as Fernanda Freire dos Santos (2017) states, it is necessary to understand that there is no editorial decision from the websites that have journalistically published a content in the past to release it again in a later moment. The search engine is responsible for pinching among thousands of other contents that fulfill certain criteria of search and show pages that can harm some individual's right. Thus, it is possible to affirm that search engines are responsible "for the provision of potentially infringing content to the fundamental 
personality rights for presenting as a research's result information that does not demonstrate current public interest due to inaccuracy and anachronism" (SANTOS, 2017).

If the content of the original page on the website is not pleaded to be deleted or edited, but just de-indexed from the search results, there would be, on one hand, the maintenance of the original content, although with less visibility, sacrificing to a lesser extent the communicative freedoms and recognizing the historical value of information, and, on the other hand, the creation of difficulties to access pages indiscriminately, which means, pages that are not related to the original context of a content potentially harmful to the individual to which it refers.

Although there is no legal provision that expressly assures the right to deindexation, there is not a single rule in the legal system that prohibits it and, as will be proved below, it is a technically feasible, adequate, effective and legally enforceable procedure against search engines companies. In addition, its recognition promotes the reconciliation between the right to be forgotten and communicative freedoms.

The acceptance of the pleading for de-indexation as a fundamental instrument to protect the right to be forgotten is not enough developed by the brazilian legal doctrine. In spite of the scarcity of bibliographical production about it and the contrary position of the Superior Court of Justice, considering the repositories of jurisprudence of the four brazilian southeastern region's state courts of justice, there is considerable acceptance in the State Court of Justice of São Paulo (SCJSP), to a lesser extent in Rio de Janeiro and Minas Gerais, while in Espírito Santo there were no demands on this matter. A recent decision of the SCJSP clearly states the legal feasibility of the de-indexation suit:

Precisely because of this, Google, the largest and most used search engine in the global scope, indisputably facilitates the dissemination of materials transmitted by electronic networks, regardless of the lawfulness of its content. It is not desired, nor is it intended, that there be a prior inspection of the content of all the results presented by the search that is carried out. However, with the power, influence and dominance exercised by the appealed party [Google] to modern society, repressed and at the same time exposed to the virtual environment, a minimum of responsibility and commitment to the legal norms brazilian legal order, constantly violated in this contemporary context. This is the so-called professional risk of the 
entrepreneur. [...] Thus, although the research provider has no responsibility for the contents of the localized virtual pages, nor for the previous censorship of such content, it is entirely possible to compel Google to limit the disclosure of the illegal content informed by the interested party, even if it has not previously insurgent against the publisher. The issue, therefore, is not to violate or restrict the right to information and freedom of expression of thought, but to prevent the dissemination / propagation of illegal content and the aggravation of the harm suffered by the injured party. (SCJSP, Civil Appeal nr. 1132494-75.2015.8.26.0100, $3^{\text {rd }}$ Private Law Chamber, Reporting Judge Beretta da Silveira, trial in: June $20^{\text {th }}, 2017$, DJe: June $\left.20^{\text {th }}, 2017\right)$. (Free translation).

As seen, although there is no legal provision which expressly guarantees the right to de-indexation, the aforementioned decision presents consistent arguments that justify its recognition.

Based on the premise that the activity of search engines configures personal data processing, it should be clarified that it is not a question of treatment done manually and individually according to a specific will to cause disruption to individuals who have content on the web. The mechanism of operation of these engines is robotic and automatic and the results are presented in order of relevance that obeys the complex algorithms developed by the company's programmers, which considerate, for example, the number of times that the webpage has been linked by other websites, the frequency of times that the searched term appears on the webpage, the location of the searched term in the text of the webpage etc (BENEVIDES and FACHETTI, 2016).

Thus, before the allegedly harmed individual manifests itself, it is impossible for the search engine to identify any damage caused by its search. Consequently, no action can be brought against it in order to reverse that situation.

This means that, at first, the possibility of filing an indemnification action against the search engine company is not feasible, not only in light of the provisions of article $19^{\text {th }}$ of the Civil Landmark of the Internet, but due to the logical consequence of these search engines activity mechanism:

Art. $19^{\text {th }}$. In order to ensure freedom of expression and to prevent censorship, the internet application provider may only be held liable for damages arising from content generated by third parties if, following a specific court order, it does not take steps to technical limits of its service and within the period indicated, make 
unavailable the content indicated as infringing, except as otherwise provided by law. (Free translation).

Such understanding is maintained even if the allegedly harmed individual extrajudicially reports the search engine on its alleged violation of law. This is because search engines in Brazil are not yet prepared to make a proper judgment on the weighting of conflicting rights, which must be done by a judge.

Therefore, the lawsuit that seems to be adequate to the protection of the right to be forgotten through de-indexation is the affirmative covenant action against the search engine company, pleading the condemnation of the company to remove the links that lead the internet user to the page in which it is stored the harmful content, without prejudice of a subsequent indemnification action due to non-compliance with the judicial decision of the affirmative covenant action.

\subsection{PLEADINGS}

The generic plea, as already explained, is the removal of links that lead the user to the page where the harmful content is stored. However, there are two exclusion methodologies that are usually pursued: 1) creation of keyword filters in searches and 2) removal of specific links, whose URL's were individually pointed out by the victim (SANTOS, 2017).

The first methodology, the creation of filters in searches that prevent the appearance of results that lead to certain keywords as a search criterion, is effective but has flaws. The two main flaws were pointed out by Justice Nancy Andrighi in Xuxa Meneghel vs. Google Search case, which are the facility to deceive through the use of synonymous terms, as well as the excessive coverage of the measure, which would prevent other searches that share the same keyword but that do not aim to locate the infringing content. Thus, because of this inadequacy (not being able to conceal the content of the search results), but mainly due to the huge damage to the right to information because of the excessive coverage of the measure, this mechanism is legally infeasible. 
As for the second methodology, the removal of links from webpages specifically indicated by the victim as violators of their personality right, it is possible to affirm that it does not present substantial failures. In spite of giving more work to the victim, who will need to list all URL's that appear in the search result that he or she understands to have violated his rights (MOCELLIN, 2017), the two problems mentioned in the previous methodology are overcomed, and the experience in other countries has demonstrated the technical feasibility of the measure. So, since this method is the least onerous measure to other rights and of greater efficiency to the right to be forgotten, it is proven to be more useful and effective.

\subsection{LEGITIMACY OF THE DEFENDANT AND CO-DEFENDANCY}

In order to satisfy the claim of removal of webpages that convey content that the individual understands as violator of his or her personality rights, the lawsuit must, without a doubt, be directed to the website manager that hosts such webpage, not being legally possible to demand against the search engines on this pleading.

However, the search engine company is responsible for personal data processing in the development of its activity, and, as already seen, this data treatment, by itself, regardless of the judicial decision against the website that originally stores the indicated content as injurious, can be the great cause of the damage to the personality right. In this way, it is quite possible that there are cases in which the content hosted in the website is not required to be removed from the web, but the search engine company is condemned to remove from the search results links that lead to those same websites. Thus, regarding the pleading for de-indexation, the search engine has the duty to satisfy the claim of the injured individual and therefore has legitimacy to integrate the passive side of the lawsuit.

If the injured party wishes to de-indexate the content as well as its exclusion, he or she may, based on article 113, III, of the Code of Civil Procedure (CCP/15), file a single lawsuit indicating as co-defendants the website that originally hosts the content and the search engine company. 


\subsection{PROCEDURAL INTEREST}

The procedural interest in filing a lawsuit against the search engine company aiming at the de-indexation of harmful content is verified in the utility and the need of the victim in obtaining the judicial protection. There are no extrajudicial mechanisms to plead for the de-indexation of content in research results and it is not part of the search engines policy that operates in Brazil to solve this situation directly. Therefore, even if search engines set out to analyze the requests themselves and grant them in cases that they consider appropriate like it has been done in the European Union, this does not seem to be the appropriate solution since, as TEFFÉ and BARLETTA (2016) argue, by the lack of objective criteria, this empowerment of search engine companies could generate damage and disproportionate restriction on freedom of expression.

In addition, the de-indexation is shown as an appropriate claim to the victim's factual situation, since it is a less burdensome measure that overcomes a series of difficulties that would be faced by the injured party who had as only alternative the filing of a lawsuit against the party that edited or made available the original content, which are, in a free translation:

a) Inability to identify the person responsible for the page, since it is possible to create or emulate false IP's; b) identification of the responsible party, but impossibility of finding his or her location; $c$ ) impossibility to submit the responsible party to the national jurisdiction, since the internet is global and the aggressor can often only be sued through international cooperation; d) the offense is so serious and harmful that it requires urgent measures; e) the aggression is carried on a large number of pages, making it unfeasible to file lawsuits against all of them, whether by autonomous lawsuits or by passive joinder; f) although located and sued by the aggressor, the latter, in spite of all coercive means, refuses to withdraw the contents of the web. (BENEVIDES and SILVESTRE, 2016).

\subsection{FINE IN CASE OF NON-COMPLIANCE AND INDEMNIFICATION ACTION}

After the prosecution, if the search engine company is senteced to de-indexate the content and refuses to comply with the judicial determination, the judge may determine 
ex officio or at the victim's request the imposition of a fine, according to the article 536, caput and $\S 1^{\text {st }}$ of the CCP/15.

At the same time, if the judicial determination is not obeyed and the victim is found to have suffered damage, there is a possibility of filing a suit for moral damages and eventual property damages.

\subsection{POSSIBILITY OF PROVISIONAL PROTECTION}

If the plaintiff (victim of the harm) is experiencing damage or danger of serious damage that is incompatible with the normal duration of the procedure, he or she may apply for provisional emergency protection, which according to article 300 of the CCP/15 must be granted by the judge when there are elements that evidence the likelihood of the right and the danger of harm or risk to the procedure useful outcome.

It is necessary, however, that the plaintiff produces evidence that shows the existence of a risk to the procedure useful outcome, which is the non-random and indiscriminate exposure of the content. Such proof does not tend to be complex, since it is sufficient that the victim indicates the webpages, which are accessed daily by an indeterminate number of internet users. In addition, the probability of the right must be evidenced, which must be well grounded in the characterization of the right to be forgotten as a personality right, also guaranteed by the brazilian Federal Constitution of 1988, and in the identification that the right to de-indexation is part of the right to be forgotten and an important tool for its virtual implementation in a faster and more effective way.

It should be noted that, according to the paragraph $3^{\text {rd }}$ of article 300 of the CCP/15, there is no danger of irreversibility of the decision's effects, since the measure of deindexation does not erase the content itself, which remains available on the websites of source, but excludes only the shortcut for access to certain pages of those websites. 


\section{CONCLUSION}

This research revealed that the right to be forgotten, which before the popularization of the internet presented as the greatest challenge to its protection the conflict with communicative freedoms, began to face new and complex obstacles in the digital environment, namely:

- mass replication and content viralization;

- transnationalization of sources;

- $\quad$ ease of anonymity of those who commit illicit practices;

- content eternalization; and

- $\quad$ convinience of searches.

It is a problem that is not restricted to the brazilian society, but a global phenomenon arising from the dynamicity of the social relations of contemporary societies and the structure and functioning of the virtual environment

The research also detected that the brazilian Judiciary is still limited to analyze the issue in terms of the prevalence or not of the right to be forgotten over other rights, in a relation "injured party versus content carrier", avoiding focussing on the activity of external parties to this dual relation. Other legal systems, such as those of the European Union and the United States, have already overcome the two-subject relationship paradigm, focusing on the role that search engine companies play in doing harm and the role that these companies could play in mitigating the damage.

In addition, the research has shown that, although the United States and the European Union present opposite understandings on the legal feasibility of filing a lawsuit aiming at the data de-indexation to the protection of the right to be forgotten, both start from the same premise: far from being neutral and passive, search engines do a data processing activity. The difference is that while the United States favour the prevalence of freedom of expression protected by the First Amendment of their Constitution, the European Union privileges the privacy and protection of personal data. 
In Brazil, the supreme courts have regulated the matter by the precedent of the Superior Court of Justice (SCJ) stated in the Xuxa Meneghel vs. Google Search case (REsp nr. 1.316.921/RJ), which starts from the premise that search engines are neutral and determines that lawsuits aimed to protect the right to be forgotten should be filed against the party that originally disclosed the content and never against the search engine company.

In relation to this judicial position, it was concluded that the premise of search engine's neutrality is wrong, since companies process data by means of complex algorithms, which interfere directly in the order of results. Accepting the neutrality argument prevents the understandment of search engine activity and prevents the development of efficient mechanisms to protect the right to be forgotten in a way that is fast and compatible with another conflicting rights.

Based on the premises established on the right to be forgotten in this research, the main peculiarities and procedural aspects of a lawsuit aimed at protecting this right by pleading the de-indexation of certain results were identified. Finally, the research concludes by the feasibility of filing an affirmative covenant action against the search engines companies claiming the aforementioned measure.

This conclusion leads, consequently, to the proposal to overrule the precedent issued by the SCJ in the decision of the REsp nr. 1.316.921/RJ, since search engines have an essential role on the national and international dissemination of web content (MOREIRA and MEDEIROS, 2016) and this proposal can be reached through a dialogue with the decision of the Court of Justice of the European Union (CONCl and GERBER, 2015).

\section{REFERENCES}

BENEVIDES, Nauani Schades; SILVESTRE, Gilberto Fachetti. O papel do google na eficácia do direito ao esquecimento: análise comparativa entre Brasil e Europa. Revista de Direito Privado. v. 17. p. 99-122. São Paulo: RT, 2016. 
CONCI, Luiz Guilherme Arcaro; GERBER, Konstantin. Diálogo judicial, proteção de dados e soberania informativa. p. 259-276. In: Gustavo Artese. (Org.). Marco Civil da Internet. 1. ed. São Paulo: Quartier Latin, 2015.

CURY NETO, Davi. Tutela do direito ao esquecimento. Dissertação (Mestrado). São Paulo: Pontificia Universidade de São Paulo, 2015.

KEEN, Andrew. Digital Vertigo: How today's online social revolution is dividing, diminishing, and disorienting us. London: Constable \& Robinson, 2012.

MOCELLIN, Caroline. A responsabilidade civil dos provedores por danos Decorrentes de conteúdo gerado por terceiro no marco civil da internet. Revista de Direito Privado. v. 83. p. 15-42. São Paulo: RT, 2017.

MOREIRA, Rodrigo Pereira; MEDEIROS, Jaquelaine Souza. Direito ao esquecimento: entre a sociedade da informação e a civilização do espetáculo. Revista de Direito Privado. v. 70. p. 71-98. São Paulo: RT, 2016.

RULLI JÚNIOR, Antônio. RULLI NETO, Antônio. Direito ao esquecimento e o superinformacionismo: apontamentos no direito brasileiro dentro do contexto de sociedade da informação. RIDB - Revista do Instituto do Direito Brasileiro, ano 1, n. 1, p. 419-434. Lisboa: IDB, 2012.

SANTOS, Fernanda Freire dos. Direito ao esquecimento: colisões entre liberdades comunicativas e direitos fundamentais da personalidade. Dissertação. (Mestrado). São Paulo: Pontifícia Universidade Católica de São Paulo, 2017.

STATCOUNTER GLOBAL STATS. Desktop, Tablet \& Console Search Engine Market Share in Brazil - Apr 2018. Disponível em: <http://gs.statcounter.com/search-enginemarket-share/desktop-tablet-console/brazil\#monthly-201804-201804-bar>. Acesso em: 22 abr. 2018.

TEFFÉ, Chiara Spadaccini de. Responsabilidade civil e liberdade de expressão no Marco Civil da Internet: a responsabilidade civil dos provedores por danos decorrentes de conteúdo gerado por terceiros. Revista de Direito Privado. v. 16. p. 59-83. São Paulo: RT, 2015.

; BARLETTA, Fabiana Rodrigues. O direito ao esquecimento: uma expressão possível do direito à privacidade. Revista de Direito do Consumidor. v. 105. p. 33-64. São Paulo: RT, 2016.

TRIGUEIRO, Fábio Vinícius Maia. Direito ao esquecimento: dimensão da intimidade e identidade pessoal. Revista de Direito Constitucional e Internacional. v. 98. p. 83-107. São Paulo: RT, 2016. 
VICENTE, Dário Moura. Direito Internacional Privado, Problemática Internacional da Sociedade da Informação. Lisboa: Universidade de Lisboa, 2004.

VOLOKH, Eugene; FALK, Donald M. First Amendment Protection for Search Engine Search Results. Jornal of Law, Economics \& Policy, Chicago, v. 8, p 883-899, 2012. Disponível em <http://www2.law.ucla.edu/volokh/searchengine.pdf>. Acesso em 02 abr. 2018.

ZANETI JR, Hermes. O valor vinculante dos precedentes: teoria dos precedentes normativos formalmente vinculantes. 2. ed. Salvador: JusPodivm, 2017. 